\title{
ANALISIS NIAT PERILAKU ANGGOTA KOMUNITAS HIJABERS SURABAYA DALAM MENGGUNAKAN TABUNGAN SYARIAH: PERSPEKTIF THEORY OF PLANNED BEHAVIOR
}

\author{
Cecia Rahmadanty \\ cecia-r-11@feb.unair.ac.id \\ Masmira Kurniawati \\ Departemen Manajemen Fakultas Ekonomi dan Bisnis Universitas Airlangga
}

\begin{abstract}
A large number of muslim population in Indonesia have an impact on the development of muslim fashion in Indonesia and led to the emergence of muslim communities such as Hijabers Surabaya community. Hijabers Surabaya community also linked himself with sharia, such as cooperation with the islamic banking in which all community members will get free sharia account when joining the community. This research focuses on the behavior and attitude of community members towards the use of sharia account by using the theory of planned behavior perspective. This study used Structural Equation Model. Total participants in this study amounted to 150 members. The results obtained in this study is: (1) Behavior belief affect the attitude toward behavior. (2) Normative belief not effect the subjective norm. (3) Motivation to comply not effect the subjective norm. (4) Control belief affect the perceived behavioral control. (5) Attitude toward behavior affect the intention to use. (6) Subjective norm not affect the intention to use. (7) Perceived behavioral control not affect to the intention to use.
\end{abstract}

Keywords: Behavior Belief, Normative Belief, Motivation to Comply, Control Belief, Attitude Toward Behavior, Subjective Norm, Perceived Behavioral Control.

\section{Pendahuluan}

Indonesia merupakan negara yang memiliki jumlah penduduk muslim paling besar di dunia. Ada sekitar 209.120.000 orang di Indonesia yang memeluk agama Islam. Angka ini mencakup 13,1 persen dari jumlah populasi muslim dunia (Mapsofworld.com 2012). Banyaknya jumlah penduduk muslim di Indonesia berdampak kepada perkembangan fashion muslim di Indonesia yang disebabkan karena banyaknya wanita muslimah di Indonesia yang menggunakan busana muslim. Perkembangan fashion muslim di Indonesia ini menyebabkan semakin banyaknya komunitas muslim yang bermunculan seperti komunitas Hijabers Surabaya.

Komunitas Hijabers Surabaya adalah sebuah komunitas pemakai kerudung modern yang memiliki visi yaitu membentuk wanita muslim yang kreatif, smart, fashionable dan 


\section{Cecia Rahmadanty Masmira Kurniawati}

berprestasi, yang santun dan ramah, sedangkan misinya yaitu mengajak kaum muslimah untuk menutup auratnya dengan cara berhijab yang fashionable, nyaman dan stylish tetapi tetap syar'i, juga menjalin tali silahturohim antara wanita muslim dalam syiar, mengajak wanita muslimah tampil cantik lahir batin, smart dan berwawasan global. Menariknya, manfaat ketika menjadi anggota komunitas tersebut yaitu setiap angggota mendapatkan tabungan syariah hanya dengan berkontribusi sebesar Rp 70.000 (Facebook Hijabers Surabaya, 2011). Bank syariah sengaja dipilih oleh komunitas Hijabers Surabaya karena mereka mengaitkannya dengan latar belakang komunitas, yaitu sama-sama mengandung prinsip islam. Strategi ini dilakukan dengan menjalin ikatan kerjasama antara pihak perbankan dengan suatu kelompok tertentu untuk mengunakan produk-produk perbankan bagi para anggotanya dimana komunitas menjadi referensi bagi anggotanya.

Penelitian ini mencoba untuk menjelaskan perilaku konsumen khususnya anggota komunitas hijabers dalam mengunakan tabungan syariah karena pengaruh dari komunitas sebagai kelompok acuan (reference group) bagi seorang individu. Komunitas adalah sekumpulan orang yang saling berbagi masalah, perhatian atau kegemaran terhadap suatu topik dan memperdalam pengetahuan serta keahlian mereka dengan saling berinteraksi secara terusmenerus (Wenger et al 2012). Sedangkan dari perspektif pemasaran, kelompok acuan atau komunitas adalah kelompok yang berfungsi sebagai kerangka acuan bagi individu dalam keputusan pembelian atau konsumsi mereka (Rorlen 2007).

Intensi untuk berperilaku dapat diprediksikan dari attitude toward behavior, subjective norm, dan perceived behavior control (Ajzen 1991). Attitude toward behavior menjelaskan tentang sejauh mana seseorang memiliki evaluasi (menguntungkan atau tidak menguntungkan) atau penilaian dari perilaku tersebut (Ajzen 1991). Dengan kata lain, sikap terhadap perilaku adalah evaluasi positif atau negatif seseorang terhadap suatu perilaku tertentu. Ketika individu memiliki sikap yang lebih positif, maka niat atau perilakunya akan lebih positif dan sebaliknya (Taylor dan Todd 1995). Pembentuk variabel attitude toward behavior dipengaruhi oleh behavioral belief (Ajzen 2002), dimana behavioral belief didefinisikan sebagai keyakinan akan hasil dari suatu perilaku dan evaluasi terhadap hasil perilaku tersebut (Hidayat dan Nugroho 2010). Jika anggota merasa dengan menggunakan tabungan syariah akan mendatangkan manfaat baginya, maka anggota akan memilih untuk menggunakannya dan sebaliknya.

Subjective norm adalah tuntutan dan keinginan dari orang-orang yang dianggap penting oleh individu. Tuntutan yang dimaksud adalah tuntutan perilaku yang sebaiknya dilakukan atau tidak dilakukan oleh individu. Dengan kata lain, norma subjektif adalah tekanan sosial yang dipersepsikan oleh seseorang untuk melibatkan diri atau tidak melibatkan diri dalam 
sebuah perilaku (Arum dan Mangkunegara 2010). Subjective norm dipengaruhi oleh dua komponen yaitu normative beliefs dan motivation to comply (Mulya 2009). Normative beliefs berkenaan dengan keyakinan tentang harapan-harapan yang berasal dari referent atau orang/kelompok yang berpengaruh bagi individu (significant others) seperti orang tua, pasangan, teman dekat, rekan kerja atau lainnya, tergantung pada perilaku yang terlibat (Ajzen 2005 dalam Arum dan Mangkunegara 2010), sedangkan motivation to comply menurut adalah motivasi atau kemauan seseorang untuk memenuhi atau tidak harapan dari significant others dengan segala pertimbangan dan resiko yang akan dihadapinya yang akhirnya mempengaruhi intensi mereka (Yogatama 2013). Secara umum, anggota komunitas Hijabers Surabaya yang yakin bahwa banyak referent yang membuat dirinya termotivasi untuk mengikuti dan berpikir bahwa dirinya harus menampilkan perilaku, maka anggota akan merasakan tekanan sosial untuk melakukannya yaitu dengan menggunakan tabungan syariah (Arum dan Mangkunegara 2010).

Perceived behavior control adalah keyakinan seseorang tentang mudah atau sulitnya perilaku yang mungkin dilakukan (Ajzen \& Madden 1986). Menurut theory of planned behavior, keyakinan mengenai tingkat kesulitan dalam berperilaku pada akhirnya akan menentukan niat. Pembentuk variabel perceived behavioral control adalah control belief (Ajzen 2002). Control belief adalah persepsi seseorang tentang adanya sumber daya dan kesempatan yang dibutuhkan untuk melakukan perilaku tertentu. Faktor kontrol memiliki dua kategorisasi yaitu faktor internal dan eksternal (Ajzen 1998) dalam Kim et al 2013). Faktor internal berhubungan dengan pengetahuan atau self-efficacy, misalnya keterampilan, kemampuan, kehendak, dan pemaksaan, sedangkan faktor eksternal berhubungan dengan lingkungan, misalnya waktu, kesempatan, dan ketergantungan pada orang lain (Ajzen 1991).

Semua variabel diatas nantinya akan berdampak pada perilaku anggota komunitas Hijabers Surabaya yang ditunjukkan melalui intensi untuk berperilaku yaitu menggunakan atau tidak menggunakan tabungan syariah. Dimana intensi adalah besarnya keinginan seseorang untuk melakukan suatu hal atau memunculkan perilaku (Yogatama 2013). Intensi dapat digunakan untuk memprediksi seberapa kuat keinginan individu untuk menampilkan tingkah laku dan seberapa banyak usaha yang direncanakan atau dilakukan individu untuk melakukan tingkah laku tersebut (Ajzen 1988 dalam Mulya 2009).

Berdasarkan latar belakang penelitian ini, maka terdapat rumusan masalah sebagai berikut (1) Apakah behavioral belief akan berpengaruh terhadap attitude toward behavior dalam menggunakan tabungan syariah? (2) Apakah normative beliefs akan berpengaruh 


\section{Cecia Rahmadanty Masmira Kurniawati}

terhadap subjective norm dalam menggunakan tabungan syariah? (3) Apakah motivation to comply akan berpengaruh terhadap subjective norm dalam menggunakan tabungan syariah? (4) Apakah control belief akan berpengaruh terhadap perceived behavioral control dalam menggunakan tabungan syariah? (5) Apakah attitude toward behavior akan berpengaruh terhadap intensi untuk menggunakan tabungan syariah? (6) Apakah subjective norm akan berpengaruh terhadap intensi untuk menggunakan tabungan syariah? (7) Apakah perveived behavioral control akan berpengaruh terhadap intensi untuk menggunakan tabungan syariah? dan tujuan dalam penelitian ini adalah untuk (1) Mengetahui pengaruh behavioral belief terhadap attitude toward behavior dalam menggunakan tabungan syariah. (2) Mengetahui pengaruh normative beliefs terhadap subjective norm dalam menggunakan tabungan syariah (3) Mengetahui pengaruh motivation to comply terhadap subjective norm dalam menggunakan tabungan syariah. (4) Mengetahui pengaruh control belief terhadap perceived behavioral control dalam menggunakan tabungan syariah. (5) Mengetahui pengaruh attitude toward behavior terhadap intensi untuk menggunakan tabungan syariah. (6) Mengetahui pengaruh subjective norm terhadap intensi untuk menggunakan tabungan syariah. (7) Mengetahui pengaruh perceived behavioral control terhadap intensi untuk mengunakan tabungan syariah.

\section{Landasan Teori dan Pengembangan Hipotesis}

\section{A. Komunitas}

Komunitas adalah sekumpulan orang yang saling berbagi masalah, perhatian atau kegemaran terhadap suatu topik dan memperdalam pengetahuan serta keahlian mereka dengan saling berinteraksi secara terus-menerus (Wenger et al 2002). Ikatan yang kuat dan dukungan dari sesama anggota komunitas memungkinkan adanya saling ketergantungan diantara anggota komunitas yang secara sadar maupun tidak terjadi interaksi saling memanfaatkan diantara anggota komunitas (Ulfa dkk 2014).

\section{B. Bank Syariah}

Perbankan syariah atau perbankan islam adalah suatu sistem perbankan yang pelaksanaannya berdasarkan hukum islam atau prinsip syariah. Prinsip syariah adalah prinsip hukum Islam dalam kegiatan perbankan berdasarkan fatwa yang dikeluarkan oleh lembaga yang memiliki kewenangan dalam penetapan fatwa di bidang syariah (UU No. 21 tahun 2008). Pertumbuhan perbankan syariah jauh lebih tinggi dari pertumbuhan perbankan nasional dan berhasil meningkatkan porsi perbankan syariah dalam perbankan nasional menjadi 4,0\% (Alamsyah 2012). Apalagi, 95\% konsumen muslim saat ini melihat label halal sebuah produk sebelum menggunakannya. Artinya, sebenarnya bank syariah memiliki potensi untuk merebut pangsa pasar masyarakat Islam Indonesia (Republika Online 2014). 


\section{Theory of Planned Behavior (TPB)}

Menurut theory of planned behavior, seseorang akan menampilkan sebuah perilaku jika orang tersebut meyakini bahwa perilaku yang dilakukannya memberikan manfaat tertentu, dan seseorang juga meyakini bahwa referent berpikir bahwa orang tersebut seharusnya melakukan suatu perilaku, serta seseorang juga akan menampilkan suatu perilaku jika orang tersebut memiliki kontrol yang cukup (Ajzen 1985 dalam Prastiwi 2010). Ketiga hal tersebut akan mempengaruhi intensi yang selanjutnya akan mengakibatkan perilaku (Yogatama 2013).

\section{Attitude Toward Behavior}

Attitude toward behavior didefinisikan sebagai evaluasi dan kecenderungan seseorang untuk bereaksi atau berespon terhadap suatu objek sikap. Objek sikap dapat berupa benda, peristiwa, orang, fenomena, ataupun hal-hal lain. Sikap menentukan penilaian seseorang untuk menyukai atau tidak menyukai (favorable-unfavorable) terhadap objek sikap tersebut. Sikap terhadap suatu perilaku dipengaruhi oleh keyakinan bahwa perilaku tersebut akan membawa kepada hasil yang diinginkan atau tidak diinginkan. Dalam theory of planned behavior, sikap secara langsung akan mempengaruhi intensi (Yogatama 2013)

\section{E. Subjective Norm}

Subjective norm merupakan pembentuk perilaku individu dimana pandangan yang dimiliki oleh orang lain berupa menyetujui atau menolak perilaku yang dilakukan oleh individu yang bersangkutan. Apabila orang lain setuju pada perilaku yang ditunjukkan individu, maka perilaku ini akan dilakukan terus menerus karena individu merasa bahwa perilaku yang dilakukan dapat diterima oleh masyarakat. Namun apabila perilaku yang ditunjukkan tidak diterima oleh orang lain, maka hal tersebut tidak akan diulangi lagi oleh individu (Agustiantono 2012). Dengan kata lain, subjective norm adalah tekanan sosial yg dirasakan untuk melakukan atau tidak melakukan perilaku (Ajzen 1991).

\section{F. Perceived Behavioral Control}

Perceived Behavioral Control (PBC) didefnisikan sebagai kemudahan atau kesulitan yang dipersepsikan untuk melakukan perilaku (Ajzen \& Madden 1986). PBC merupakan keyakinan individu mengenai seberapa besar kontrol yang dimilikinya untuk memunculkan perilaku (Yogatama 2013) dan PBC juga didefinisikan sebagai kontrol perilaku konsumen atas dirinya sendiri atau tindakannya dalam mempertimbangkan perilakunya dalam sebuah komunitas tertentu (Ajzen 1991).

\section{G. Behavioral Belief}

Behavioral belief yaitu keyakinan akan hasil dari suatu perilaku dan evaluasi terhadap hasil perilaku tersebut (Hidayat dan Nugroho 2010). Dengan kata lain, seseorang yang yakin 


\section{Cecia Rahmadanty Masmira Kurniawati}

bahwa sebuah tingkah laku dapat menghasilkan outcome yang positif, maka ia akan memiliki sikap yang positif, begitu juga sebaliknya (Arum dan Mangkunegara 2010). Keinginan seseorang untuk menampilkan sebuah perilaku tergantung pada evaluasi seseorang, apakah mereka memiliki evaluasi positif (bermanfaat, penting, menyenangkan, dan sebagainya) atau memiliki evaluasi negatif (menganggu, tidak penting, malas, dan sebagainya).

\section{H. Normative Belief}

Normative belief adalah kepercayaan seseorang tentang bagaimana significant others berpikir atau mengharapkan seseorang melakukan sesuatu atau tidak melakukannya sama sekali (Yogatama 2013). Normative belief adalah harapan-harapan dari referent individu atau kelompok penting yang menyetujui atau menolak perilaku atas tindakan seseorang (Ajzen 1991). Normative belief juga didefinisikan sebagai keyakinan individu terhadap tekanan sosial dimana individu atau kelompok tertentu berpikir bahwa ia harus atau tidak harus melakukan perilaku (Pookulangara et al 2011).

\section{Motivation to Comply}

"Motivation can be described as the driving force within individuals that impels them to action" (Schiffman dan Kanuk 2007). Artinya, motivasi adalah kekuatan pendorong dalam diri seseorang yang memaksanya untuk melakukan suatu tindakan, sedangkan motivation to comply didefinisikan sebagai dorongan atau kemauan seseorang untuk memenuhi atau tidak harapan significant others dengan segala pertimbangan dan resiko yang akan dihadapinya yang akhirnya mempengaruhi intensi mereka (Yogatama 2013).

\section{J. Control Belief}

Control belief adalah keyakinan individu tentang keberadaan hal-hal yang mendukung atau menghambat perilakunya dan persepsinya tentang seberapa kuat hal-hal tersebut mempengaruhi perilakunya (Hidayat dan Nugroho 2010). Artinya, sesorang akan merasa mudah untuk melakukan atau menampilkan suatu perilaku tertentu apabila mereka memiliki dukungan yang kuat untuk mempengaruhi perilaku mereka. Dukungan yang dimaksud adalah adanya sumber daya yang cukup, kemauan, waktu, kesempatan, dan sebaliknya.

\section{K. Intention to Use}

Niat atau intensi didefinisikan sebagai rencana untuk melakukan perilaku tertentu dan merupakan faktor yang paling penting untuk memprediksi perilaku secara langsung (Ajzen 1991 dalam Kim et al 2013). Intensi menunjukkan seberapa besar seseorang memiliki keinginan untuk melakukan suatu hal atau memunculkan perilaku. individu untuk melakukan tingkah laku tersebut (Ajzen 1988 dalam Mulya 2009). Dalam theory of planned behavior, faktor utama dari suatu perilaku yang ditampilkan individu adalah intensi untuk menampilkan perilaku tertentu. Intensi diasumsikan sebagai faktor motivasional yang mempengaruhi perilaku. 


\subsection{Pengembangan Hipotesis}

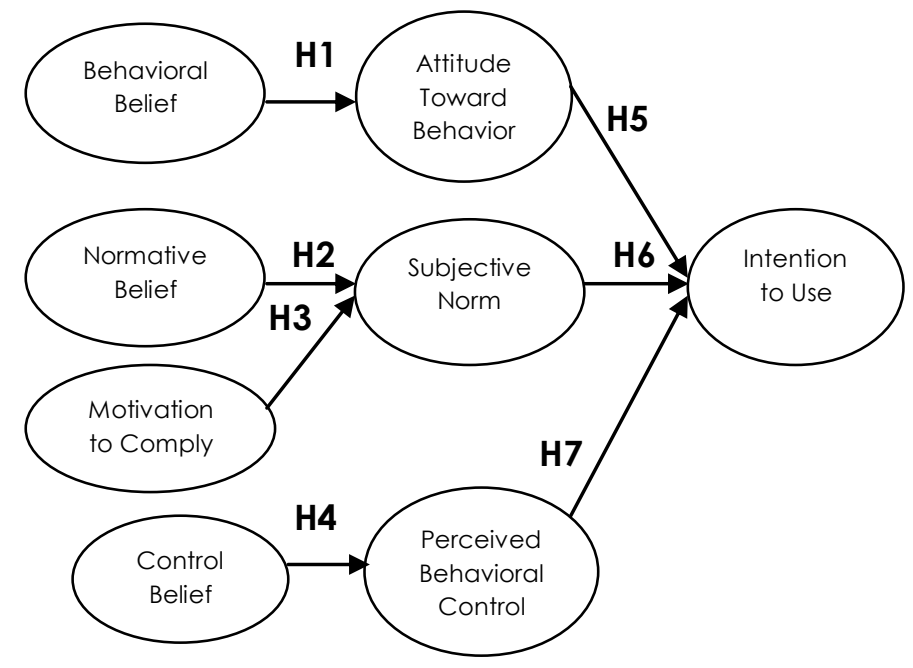

Gambar 2.1

Model Analisis

Behavioral belief adalah keyakinan akan hasil dari suatu perilaku (outcome belief) dan evaluasi terhadap hasil perilaku tersebut (Hidayat dan Nugroho 2010). Sedangkan attitude toward behavior menjelaskan tentang sejauh mana seseorang memiliki evaluasi (menguntungkan atau tidak menguntungkan) atau penilaian dari perilaku tersebut (Ajzen 1991). Jika dikaitkan, maka anggota komunitas memiliki pilihan untuk menggunakan atau tidak menggunakan tabungan syariah didasarkan pada keyakinan akan hasil yang akan didapatkan. Jika anggota merasa tidak akan ada hasil yang menguntungkan dan bermanfaat, maka anggota cenderung akan memilih untuk tidak menggunakan tabungan tersebut, dan sebaliknya. Dengan demikian didapatkan hipotesis sebagai berikut:

\section{H1. Behavioral beliefs berpengaruh terhadap attitude toward behavior dalam menggunakan} tabungan syariah.

Normative beliefs berkenaan dengan keyakinan tentang harapan-harapan yang berasal dari referent atau orang/kelompok yang berpengaruh bagi individu (significant others) seperti orang tua, pasangan, teman dekat, rekan kerja atau lainnya, tergantung pada perilaku yang terlibat (Ajzen 2005 dalam Arum dan Mangkunegara 2010). Keyakinan normatif tersebut akan mempengaruhi norma subjektif seseorang untuk menggunakan atau tidak menggunakan tabungan syariah. Subjective norm adalah tekanan sosial yg dirasakan untuk melakukan atau tidak melakukan perilaku (Ajzen 1991). Jadi, apabila anggota komunitas Hijabers Surabaya mendapatkan pengaruh dari referent dan apabila anggota memiliki keyakinan atau kepercayaan bahwa referent mengharapkan anggota untuk 


\section{Cecia Rahmadanty Masmira Kurniawati}

berperilaku, maka masing-masing anggota memiliki perilaku untuk menyetujui atau menolak pengaruh dari referent tersebut dalam hal penggunaan tabungan syariah dan didapatkan hipotesis sebagai berikut :

\section{H2. Normative beliefs berpengaruh terhadap subjective norms dalam menggunakan} tabungan syariah.

Motivation to comply adalah motivasi atau kemauan seseorang untuk memenuhi atau tidak harapan dari significant others dengan segala pertimbangan dan resiko yang akan dihadapinya yang akhirnya mempengaruhi intensi mereka (Yogatama 2013). Sedangkan subjective norm adalah tuntutan dan keinginan dari orang-orang yang dianggap penting oleh individu (siginifacant others), tuntutan yang dimaksud adalah tuntutan perilaku yang sebaiknya dilakukan atau tidak dilakukan oleh individu.

Penelitian ini menjadikan komunitas sebagai referent yang memiliki harapan kepada anggota komunitas untuk menggunakannya, sedangkan anggota komunitas mempunyai pilihan untuk mematuhi atau tidak mematuhi harapan dari referent untuk menggunakan tabungan syariah. Dengan demikian didapatkan hipotesis sebagai berikut :

\section{H3. Motivation to comply berpengaruh terhadap norma subjektif dalam menggunakan tabungan syariah.}

Control belief didefinisikan sebagai keyakinan individu tentang keberadaan hal-hal yang mendukung atau menghambat perilakunya dan persepsinya tentang seberapa kuat hal-hal tersebut mempengaruhi perilakunya (Hidayat dan Nugroho 2010). Sumber daya, kesempatan, dan berbagai hal yang mendukung tersebut yaitu seperti keterampilan, kemampuan, kehendak, pemaksaan, waktu, kesempatan, dan ketergantungan pada orang lain (Ajzen 1991). Sedangkan perceived behavioral control didefnisikan sebagai kemudahan atau kesulitan yang dipersepsikan untuk melakukan perilaku (Ajzen \& Madden 1986).

Artinya, jika anggota komunitas Hijabers Surabaya merasa bahwa mereka memiliki sumber daya, kesempatan dan hal-hal yang mendukung untuk menggunakan tabungan syariah, maka mereka memilki persepsi bahwa mereka mampu dan mudah untuk menggunakan tabungan syariah, dan sebaliknya. Maka didapatkan hipotesis sebagai berikut :

H4. Control belief mempengaruhi perceived behavior control dalam menggunakan tabungan syariah.

Sikap didefinisikan sebagai reaksi evaluatif (kognitif) terhadap sebuah tindakan dan sesuatu yang dianggap mencerminkan kecenderungan untuk menampilkan respon yang 
menguntungkan atau tidak menguntungkan (Eagly dan Chaiken 1993 dalam Wijono 2012). Sedangkan intensi didefinisikan sebagai besarnya keinginan seseorang untuk melakukan suatu hal atau memunculkan perilaku (Yogatama 2013).

Dalam penelitian ini, anggota komunitas memiliki dua kemungkinan yaitu memiliki sikap positif terhadap pembukaan tabungan syariah atau memiliki sikap negatif tentang pembukaan tabungan syariah. Hal tersebut akan mempengaruhi niat mereka dalam menggunakan tabungan syariah, sehingga didapatkan hipotesis sebagai berikut:

H5. Attitude toward behavior mempengaruhi intensi untuk menggunakan tabungan syariah.

Subjective norm adalah tekanan sosial yang dipersepsikan oleh seseorang untuk melibatkan diri atau tidak melibatkan diri dalam sebuah perilaku (Arum dan Mangkunegara 2010). Intensi didefinisikan sebagai besarnya keinginan seseorang untuk melakukan suatu hal atau memunculkan perilaku (Yogatama 2013), sedangkan intensi dapat digunakan untuk memprediksi seberapa kuat keinginan individu untuk menampilkan tingkah laku (Ajzen 1988 dalam Mulya 2009).

Norma-norma subjektif tersebut akan mempengaruhi niat anggota komunitas Hijabers Surabaya dalam menggunakan tabungan syariah. Norma subjektif yang dipengaruhi oleh orang lain akan berpengaruh secara signifikan karena seseorang seringkali juga tergantung pada penilaian orang lain. Dengan demikian, didapatkan hipotesis sebagai berikut :

H6. Subjective norm berpengaruh terhadap intensi untuk menggunakan tabungan syariah.

Perceived behavior control didefinisikan sebagai persepsi individu mengenai mudah atau sulitnya dalam menampilkan suatu perilaku dan merupakan refleksi dari pengalaman masa lalu dan antisipasi dari suatu hambatan (Ajzen 1991), sedangkan intensi dapat digunakan untuk memprediksi seberapa kuat keinginan individu untuk menampilkan tingkah laku (Ajzen 1988 dalam Mulya 2009). Jika dikaitkan, apabila seseorang memiliki perceived behavioral control yang lebih tinggi, maka keinginan atau intensi untuk berperilaku juga tinggi. Sebaliknya, jika seseorang memiliki perceived behavioral control yang rendah, maka mereka memiliki intensi yang rendah untuk berperilaku. Dengan demikian didapatkan hipotesis sebagai berikut :

H7. Perceived behavioral control berpengaruh terhadap intensi untuk menggunakan tabungan syariah.

\section{Metode Penelitian}




\section{Cecia Rahmadanty Masmira Kurniawati}

Penelitian ini menggunakan pendekatan kuantitatif karena dengan menggunakan pendekatan ini proses penelitian dapat dilakukan secara terstruktur dan membuat generalisasi pada populasi yang akan di teliti (Anshori dan Iswati 2009), sehingga dapat mengurangi error.

Tabel 3.1

Jenis dan Pengukuran Variabel

\begin{tabular}{|c|c|}
\hline Jenis Variabel & Variabel \\
\hline Eksogen & $\begin{array}{l}\text { 1. behavioral beliefs } \\
\text { 2. normative beliefs } \\
\text { 3. motivation to comply } \\
\text { 4. control belief }\end{array}$ \\
\hline Endogen & $\begin{array}{ll}\text { 1. } & \text { attitude toward behavior } \\
\text { 2. } & \text { subjective norm } \\
\text { 3. } & \text { perceived behavioral control. } \\
\text { 4. Intention to Use }\end{array}$ \\
\hline
\end{tabular}

Tabel 3.2

Definisi Operasional Variabel

\begin{tabular}{|c|c|}
\hline Variabel & Definisi Operasional \\
\hline $\begin{array}{l}\text { Attitude } \\
\text { Toward } \\
\text { Behavior }\end{array}$ & $\begin{array}{l}\text { 1. Kesukaan terhadap ide menggunakan tabungan syariah } \\
\text { 2. Tanggapan menggunakan tabungan syariah } \\
\text { 3. Ketertarikan terhadap penggunaan tabungan syariah } \\
\text { 4. Pandangan antara komunitas dengan tabungan syariah }\end{array}$ \\
\hline $\begin{array}{c}\text { Subjective } \\
\text { Norm }\end{array}$ & $\begin{array}{l}\text { 1. Persepsi mengenai tekanan sosial dari orang-orang yang } \\
\text { mempengaruhi keputusan seserorang } \\
\text { 2. Persepsi mengenai tekanan sosial dari orang-orang yang penting dalam } \\
\text { hidup seseorang } \\
\text { 3. Respon terhadap pengaruh orang-orang yang penting dalam } \\
\text { menggunakan tabungan syariah. } \\
\text { 4. Respon komunitas Hijabers Surabaya dalam perilaku menggunakan } \\
\text { tabungan syariah }\end{array}$ \\
\hline $\begin{array}{c}\text { Perceived } \\
\text { Behavioral } \\
\text { Control }\end{array}$ & $\begin{array}{l}\text { 1. Kemudahan menggunakan tabungan syariah } \\
\text { 2. Kendali dalam menggunakan tabungan syariah } \\
\text { 3. Pengetahuan dalam menggunakan tabungan syariah } \\
\text { 4. Kemampuan untuk menggunakan tabungan syariah }\end{array}$ \\
\hline
\end{tabular}




\begin{tabular}{|c|l|}
\hline $\begin{array}{c}\text { Behavioral } \\
\text { Belief }\end{array}$ & $\begin{array}{l}\text { 1. Kepercayaan akan manfaat menggunakan tabungan syariah } \\
\text { 2. Keuntungan menggunakan tabungan syariah } \\
\text { 3. Konsekuensi menggunakan tabungan syariah } \\
\text { 4. Hasil yang didapat ketika menggunakan tabungan syariah }\end{array}$ \\
\hline $\begin{array}{c}\text { Normative } \\
\text { Belief }\end{array}$ & $\begin{array}{l}\text { 2. Karapan komunitas untuk menggunakan tabungan syariah } \\
\text { tabungan syariah }\end{array}$ \\
$\begin{array}{c}\text { 3. Ajakan menggunakan tabungan syariah } \\
\text { 4. Keinginan sesama anggota komunitas untuk menggunakan tabungan } \\
\text { syariah }\end{array}$ \\
\hline $\begin{array}{c}\text { Motivation } \\
\text { to Comply }\end{array}$ & $\begin{array}{l}\text { 1. Keinginan untuk melakukan apa yang orang-orang pikir harus dilakukan } \\
\text { 2. Keinginan untuk mengikuti apa yang direkomendasikan oleh komunitas } \\
\text { 3. Keinginan untuk mengikuti teman-teman sesama komunitas }\end{array}$ \\
\hline Belief & $\begin{array}{l}\text { 1. Waktu yang dimiliki untuk menggunakan tabungan syariah } \\
\text { 2. Sumber daya yang cukup untuk menggunakan tabungan syariah } \\
\text { 3. Kesempatan menggunakan tabungan syariah } \\
\text { 4. Persepsi kemungkinan menggunakan tabungan syariah }\end{array}$ \\
\hline Intention to & $\begin{array}{l}\text { 1. Niat untuk terus menggunakan tabungan syariah } \\
\text { 2. Rencana untuk terus menggunakan tabungan syariah } \\
\text { 3. Mencoba untuk terus menggunakan tabungan syariah }\end{array}$ \\
\hline
\end{tabular}

Tabel 3.1

Jenis Skala Pengukuran

\begin{tabular}{|l|l|}
\hline Jenis Skala & \multicolumn{1}{|c|}{ Keterangan } \\
\hline Skala Likert & 1. STS = Sangat Tidak Setuju \\
& 2. TS = Tidak Setuju \\
& 3. N = Netral \\
& 4. S = Setuju \\
& 5. SS = Sangat Setuju \\
\hline
\end{tabular}

Sumber : Simamora, 2004

Pengambilan sampel dalam penelitian ini dilakukan dengan menggunakan pertimbangan tertentu. SEM mengharapkan jumlah sampel yang cukup besar, dan untuk melakukan estimasi dengan metode maximum likelihood seperti yang dilakukan dalam penelitian ini, dibutuhkan sampel antara 100-200 sampel atau minimal minimal 100 sampel (Hair dkk, 2006 dalam Waluyo, 2011). Sedangkan jumlah sampel yang ditentukan dalam penelitian ini adalah 150 sampel. Teknik pengambilan sampel dilakukan dengan probability sampling, dimana menurut Anshori dan Iswati (2009) probability sampling adalah teknik sampling yang memberikan peluang yang sama bagi setiap unsur anggota populasi yang dipilih menjadi anggota sampel. Teknik probability sampling yang digunakan dalam penelitian ini yaitu simple random sampling.

Teknik analisis data yang digunakan adalah Structural Equation Modelling diamana terdapat beberapa tahapan pemodelan dalam analisis SEM sebanyak 7 langkah yaitu (1) Pengembangan model berbasis teori (2) Pengembangan diagram alur (path diagram) (3) 


\section{Cecia Rahmadanty Masmira Kurniawati}

Konversi diagram alur ke dalam persamaan (4) Memilih matriks input dan teknik estimasi (5) Menilai problem identifikasi (6) Evaluasi Model (7) Interpretasi dan modifikasi model.

\section{Hasil dan Pembahasan}

Tabel 4.1

Hasil Pengujian Goodness of Fit Model

\begin{tabular}{|l|l|l|l|}
\hline Kriteria & Cut of value & Hasil model & \multicolumn{1}{|c|}{ Keterangan } \\
\hline CMIN/DF & $\leq 2,0$ atau $\leq 3,0$ & 2,463 & Model Fit \\
\hline GFI & $\geq 0,90$ & 0,672 & Tidak Fit \\
\hline CFI & $\geq 0,95$ & 0,778 & Model Marginal \\
\hline RMSEA & $\leq 0,08$ & 0,099 & Model Marginal \\
\hline AGFI & $\geq 0,90$ & 0,611 & Tidak Fit \\
\hline TLI & $\geq 0,95$ & 0,754 & Model Marginal \\
\hline NFI & $\geq 0,90$ & 0,681 & Tidak Fit \\
\hline PNFI & $0,60 \leq \mathrm{PNFI} \leq 0,90$ & 0,613 & Model Fit \\
\hline PGFI & $0,00 \leq \mathrm{PGFI} \leq 1,00$ & 0,567 & Model Fit \\
\hline
\end{tabular}

Sumber: Data Primer Diolah, 2015

Pengujian goodness of fit overall model menurut Solimun (2005) dalam Aryani dan Rosinta (2010), jika salah satu uji memenuhi nilai cut off value maka model sudah dianggap layak digunakan. Hasil pengujian Goodness of Fit Model berdasarkan Tabel 4.1 memperlihatkan bahwa tiga kriteria yaitu CMIN/DF, PNFI dan PGFI telah memenuhi nilai cut off value, maka model SEM pada penelitian ini cocok dan layak untuk digunakan, sehingga dapat dilakukan interpretasi guna pembahahasan lebih lanjut.

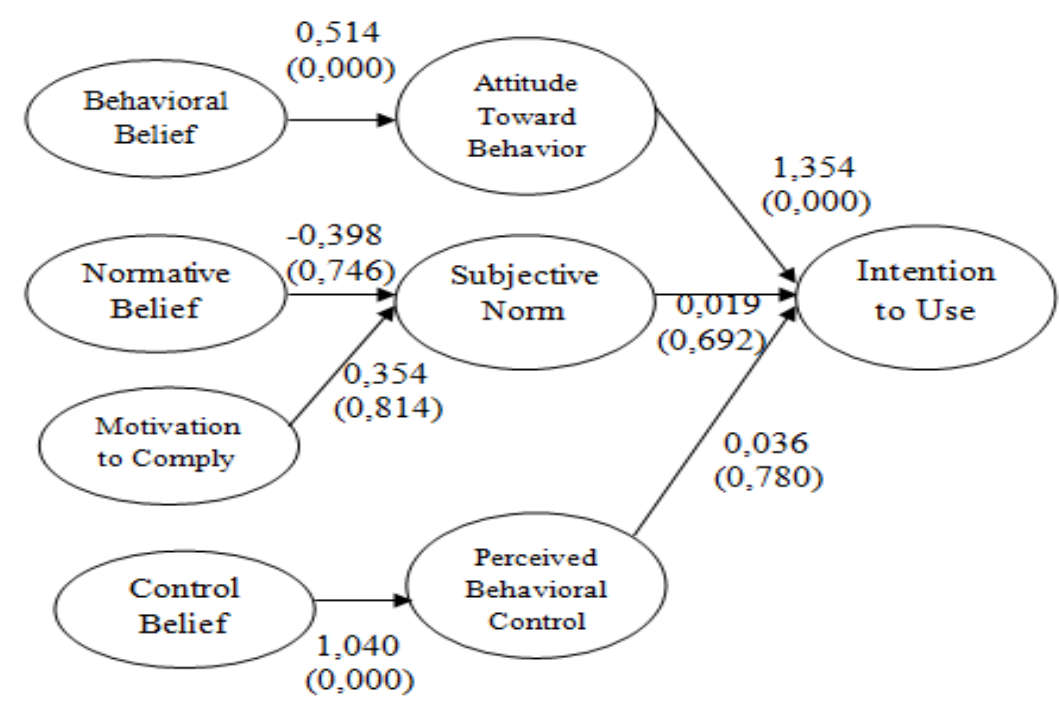

Gambar 4.1

Pengujian Hipotesis 
Berdasarkan hasil uji statistik yang telah digunakan, semua hipotesis yang diujikan telah memenuhi persyaratan atau dapat digunakan sebagai model pengukuran dalam studi ini. Tabel berikut menyajikan hasil pengujian hipotesis:

Tabel 4.18

Hasil Pengujian Hipotesis

\begin{tabular}{|c|c|r|r|r|r|c|}
\hline Hipotesis & $\begin{array}{c}\text { Hubungan } \\
\text { antar } \\
\text { variabel }\end{array}$ & Estimate & \multicolumn{1}{c|}{ S.E. } & C.R. & $\begin{array}{c}\text { P- } \\
\text { value }\end{array}$ & Keterangan \\
\hline $\mathrm{H} 1$ & $\mathrm{X} 1 \rightarrow \mathrm{Z} 1$ & 0,514 & 0,078 & 6,583 & $* * *$ & Signifikan \\
\hline $\mathrm{H} 2$ & $\mathrm{X} 2 \rightarrow \mathrm{Z2}$ & $-0,398$ & 1,230 & $-0,324$ & 0,746 & Tidak Signifikan \\
\hline $\mathrm{H} 3$ & $\mathrm{X} 3 \rightarrow \mathrm{Z2}$ & 0,354 & 1,508 & 0,235 & 0,814 & Tidak Signifikan \\
\hline $\mathrm{H} 4$ & $\mathrm{X} 4 \rightarrow \mathrm{Z3}$ & 1,040 & 0,197 & 5,272 & $* * *$ & Signifikan \\
\hline $\mathrm{H} 5$ & $\mathrm{Z1} \rightarrow \mathrm{Y} 1$ & 1,354 & 0,281 & 4,816 & $* * *$ & Signifikan \\
\hline
\end{tabular}

Sumber : Data Primer Diolah, 2015

\subsection{Pengaruh Behavioral Belief Terhadap Attitude Toward Behavior dalam Menggunakan Tabungan Syariah}

Berdasarkan pengujian hipotesis, dapat disimpulkan bahwa variabel behavioral belief memiliki pengaruh positif yang signifikan terhadap variabel attitude toward behavior. Hasil ini bermakna bahwa semakin tingginya behavioral belief seseorang, maka semakin positif atau semakin tinggi pula attitude toward behavior yang dimiliki seseorang. Dalam penelitian ini dapat diketahui bahwa anggota komunitas Hijabers Surabaya memiliki evaluasi yang positif terhadap penggunaan tabungan syariah.

\subsection{Pengaruh Normative Belief Terhadap Subjective Norm dalam Menggunakan Tabungan}

\section{Syariah}

Berdasarkan pengujian hipotesis disimpulkan bahwa variabel normative belief memiliki pengaruh negatif yang tidak signifikan terhadap variabel subjective norm. Hasil ini tidak sesuai dengan teori perilaku yang menyatakan bahwa norma subjektif responden dipengaruhi oleh keyakinan normatif yang dimiliki oleh responden tersebut. Dalam penelitian ini dapat diketahui bahwa anggota komunitas Hijabers Surabaya percaya bahwa komunitas Hijabers Surabaya mengharapkan seluruh anggota untuk menggunakan tabungan syariah, tetapi komunitas tersebut tidak memberlakukan sanksi atau hukuman apabila terdapat anggota yang tidak menggunakan tabungan syariah, sehingga anggota komunitas Hijabers Surabaya tidak merasakan adanya tekanan sosial dari kelompok komunitas yang berpikir 


\section{Cecia Rahmadanty Masmira Kurniawati}

bahwa anggota komunitas seharusnya melakukan suatu perilaku yaitu perilaku menggunakan tabungan syariah.

\subsection{Pengaruh Motivation To Comply Terhadap Subjective Norm dalam Menggunakan Tabungan Syariah}

Berdasarkan pengujian hipotesis sebelumnya, maka diketahui bahwa variabel motivation to comply memiliki pengaruh positif yang tidak signifikan dari terhadap variabel subjective norm. Hipotesis yang menyatakan bahwa motivation to comply berpengaruh terhadap subjective norm dalam penelitian ini ditolak. Hasil yang didapatkan dalam penelitian ini diketahui bahwa komunitas Hijabers Surabaya tidak memberlakukan sanksi kepada anggota dalam menggunakan tabungan syariah, sehingga sebagian besar anggota komunitas Hijabers Surabaya tidak memiliki motivasi yang tinggi yang membuat mereka tidak merasakan adanya tekanan sosial untuk mengikuti harapan komunitas yang membuat mereka berpikir bahwa mereka harus menggunakan tabungan syariah.

\subsection{Pengaruh Control Belief Terhadap Perceived Behavioral Control dalam Menggunakan Tabungan Syariah}

Berdasarkan pengujian hipotesis diatas didapat kesimpulan bahwa variabel control belief berpengaruh secara signifikan terhadap variabel perceived behavioral control yang artinya, hipotesis yang menyatakan bahwa variabel control belief memiliki pengaruh terhadap perceived behavioral control diterima, yang berarti adanya pengaruh positif yang signifikan antara variabel control belief terhadap perceived behavioral control. Dalam penelitian ini membuktikan bahwa anggota komunitas Hijabers Surabaya memiliki memiliki lebih banyak dukungan sehingga ia akan memiliki persepsi bahwa menggunakan tabungan syariah itu mudah. Maka dapat disimpulkan bahwa sebagian besar anggota komunitas Hijabers Surabaya memiliki control belief yang tinggi.

\subsection{Pengaruh Attitude Toward Behavior Terhadap Intensi Untuk Menggunakan Tabungan Syariah}

Berdasarkan pengujian hipotesis dalam penelitian ini didapatkan hasil yang menunjukkan bahwa variabel attitude toward behavior signifikan terhadap intensi untuk menggunakan tabungan syariah. Hal ini berarti bahwa hipotesis dalam penelitian ini diterima yang berarti adanya pengaruh positif yang signifikan antara variabel attitude toward behavior terhadap intensi menggunakan tabungan syariah. Dalam penelitian ini, sebagian besar anggota memiliki evaluasi positif secara menyeluruh dan mereka memiliki sikap tertarik terhadap penggunaan tabungan syariah, sehingga mereka memiliki intensi untuk berperilaku yaitu perilaku menggunakan tabungan syariah.

\subsection{Pengaruh Subjective Norm Terhadap Intensi Untuk Menggunakan Tabungan Syariah}

Berdasarkan pengujian hipotesis, maka didapat kesimpulan bahwa variabel subjective norm tidak signifikan terhadap intensi untuk menggunakann tabugan syariah. Hal ini berarti hipotesis dalam penelitian ini ditolak yang berarti adanya pengaruh positif yang tidak 
signifikan antara subjective norm terhadap intensi menggunakan tabungan syariah. Hasil dari penelitian ini tidak membuktikan bahwa subjective norm akan mempengaruhi intensi seseorang, hal ini berarti sebagian besar anggota komunitas Hijabers Surabaya tidak merasakan adanya tekanan sosial yang besar dari komunitas Hijabers, sehingga mereka merasa tidak harus berperilaku seperti yang seharusnya diharapkan oleh komunitas Hijabers Surabaya dalam perilaku menggunakan tabungan syariah.

\subsection{Pengaruh Perceived Behavioral Control Terhadap Intensi Untuk Mengunakan Tabungan Syariah}

Berdasarkan pengujian hipotesis diatas, maka didapat kesimpulan bahwa variabel perceived behavioral control memiliki hubungan yang tidak signifikan terhadap intensi untuk menggunakan tabungan syariah. Hal ini dikarenakan sebagian besar responden dalam penelitian ini adalah mahasiswa $(26,68 \%)$, dimana dalam penelitian ini, tabungan syariah adalah sebagai tabungan tambahan bagi mereka yang mereka dapatkan melalui komunitas, sebelumnya mereka telah memiliki rekening tabungan sendiri, sehingga mereka memiliki control belief atau dukungan yang terbatas seperti vang, waktu, dan kemampuan lebih untuk menggunakan tabungan syariah, hal ini yang menyebabkan mereka tidak memiliki intensi untuk terus menggunakan tabungan syariah yang mereka dapatakan melalui komunitas Hijabers Surabaya.

\section{Simpulan}

Hipotesis yang menyatakan bahwa behavioral belief berpengaruh terhadap attitude toward behavior diterima. Dalam penelitian ini dapat diketahui bahwa anggota komunitas Hijabers Surabaya memiliki evaluasi positif terhadap penggunaan tabungan syariah.

Hipotesis yang menyatakan bahwa normative belief berpengaruh terhadap subjective norm ditolak. Dalam penelitian ini ditemukan bahwa anggota komunitas Hijabers Surabaya percaya dan yakin jika komunitas mengharapkan mereka untuk terus menggunakan tabungan syariah tetapi mereka tidak merasakan adanya tekanan sosial dari komunitas.

Hipotesis yang menyatakan bahwa motivation to comply berpengaruh terhadap subjective norm ditolak. Dalam penelitian ini disimpulkan bahwa sebagian besar anggota komunitas Hijabers Surabaya tidak memiliki motivasi untuk memenuhi harapan komunitas dan teman-teman terdekatnya sesama komunitas. Hal ini disebabkan karena tidak diberlakukannya sanksi kepada anggota yang tidak terus menggunakan tabungan syariah, sehingga mereka tidak merasakan adanya tekanan sosial dari komunitas.

Hipotesis yang menyatakan bahwa control belief berpengaruh terhadap perceived behavioral control diterima. Dalam penelitian ini diketahui bahwa sebagian besar anggota komunitas Hijabers Surabaya merasa jika mereka memiliki dukungan dari komunitas untuk menggunakan tabungan syariah, sehingga mereka memiliki persepsi bahwa mereka dapat menggunakakn tabungan syariah dengan mudah. 


\section{Cecia Rahmadanty \\ Masmira Kurniawati}

Hipotesis yang menyatakan bahwa attitude toward behavior berpengaruh terhadap intention to use diterima. Dalam penelitian ini terbukti bahwa sebagian besar anggota komunitas Hijabers Surabaya memiliki respon positif terhadap ide komunitas Hijabers Surabaya dalam menggunakan tabungan syariah. Mereka memiliki evaluasi positif secara menyeluruh dan mereka memiliki sikap tertarik terhadap penggunaan tabungan syariah.

Hipotesis yang menyatakan bahwa subjective norm berpengaruh terhadap intention to use ditolak. Dalam penelitian ini disimpulkan jika sebagian besar anggota komunitas Hijabers Surabaya tidak merasakan adanya tekanan sosial dari komunitas untuk terus menggunakan tabungan syariah, maka mereka tidak memiliki intensi untuk terus menggunakan tabungan syariah.

Hipotesis yang menyatakan bahwa perceived behavioral control berpengaruh terhadap intention to use ditolak. Dalam penelitian ini dapat diketahui bahwa sebagian besar anggota komunitas Hijabers Surabaya memiliki persepsi bahwa menggunakan tabungan syariah adalah hal yang sulit bagi mereka karena sebagian besar responden dalam penelitian ini adalah mahasiswa, dimana mereka memiliki dukungan yang terbatas seperti vang, waktu, dan kemampuan.

\section{Daftar Referensi}

Agustiantono, D. (2012). Analisis Faktor-Faktor yang Mempengaruhi Kepatuhan Wajib Pajak Orang Pribadi: Aplikasi TPB. Studi Empiris WPOP di Kabupaten Pati.

Ajzen, I. (1991). The theory of planned behavior. Organizational behavior and human decision processes, 50(2), 179-211.

(2002). Constructing a TPB questionnaire: Conceptual and methodological considerations

Ajzen, I., \& Madden, T. J. (1986). Prediction of goal-directed behavior: Attitudes, intentions, and perceived behavioral control. Journal of experimental social psychology, 22(5), 453-474.

Alamsyah, H. (2012). Perkembangan dan Prospek Perbankan Syariah Indonesia: Tantangan Dalam Menyongsong MEA 2015. Ceramah IImiah Ikatan Ahli Ekonomi Islam (IAEI), Milad ke-8 IAEI, 13.

Anshori, M., \& Iswati, S. (2009). Metodologi penelitian kuantitatif. Surabaya: Pusat Penerbitan dan Percetakan UNAIR.

Arum, M. D., \& Mangkunegara, A. A. (2010). Peran Sikap, Norma Subyektif, dan Persepsi Kendali Perilaku dalam Memprediksi Intensi Wanita Melakukan Pemeriksaan Payudara Sendiri. Jurnal IImiah Psikologi, 1 (3), 162-172

Aryani, D., \& Rosinta, F. (2010). Pengaruh kualitas layanan terhadap kepuasan pelanggan dalam membentuk loyalitas pelanggan. Bisnis \& Birokrasi Journal,17(2).

Bank Indonesia \& K. U. U. H. Dagang. (2008). Undang-Undang Republik Indonesia Nomor 21 Tahun 2008 tentang Perbankan Syariah. LN Nomor, 94 
Fisher, R \& Sprott, D. E., Spangenberg, E. R., (2003). The importance of normative beliefs to the self-prophecy effect. Journal of Applied Psychology,88(3), 423.

Hidayat, W \& Nugroho A. (2012). Studi Empiris Theory of Planned Behavior dan Pengaruh Kewajiban Moral pada Perilaku Ketidakpatuhan Pajak Wajib Pajak Orang Pribadi. KOMPILASI

http://www.mapsofworld.com/world-top-ten/world-top-ten-countries-with-largest-muslimpopulations-map.html (diakses pada tanggal 10 Januari 2015)

https://www.facebook.com/hijabers.surabaya/about? section=bio/diakses pada tanggal 7 November 2014)

Kim, E., Ham, S., Yang, I. S., \& Choi, J. G. (2013). The roles of attitude, subjective norm, and perceived behavioral control in the formation of consumers' behavioral intentions to read menu labels in the restaurant industry. International Journal of Hospitality Management, 35, 203-213.

Mulya, T. (2009). Pengaruh sikap, norma subjektif, dan perceived behavioral control terhadap intensi menggunakan trans jakarta untuk pergi ke tempat kerja.

Muniz Jr, A. M., \& O'guinn, T. C. (2001). Brand community. Journal of consumer research, 27(4), 412-432.

Pookulangara, S., Hawley, J., \& Xiao, G. (2011). Explaining consumers' channel-switching behavior using the theory of planned behavior. Journal of Retailing and Consumer Services, 18(4), 311-321.

Prastiwi, W. E. (2010). Analisa Pelatihan Life Skill Untuk Meningkatkan Pengetahuan, Sikap, Norma Subyektif, dan Kontrol Perilaku (Dalam Rangka Pencegahan Hiv Aids Pada Siswa Madrasah Tsanawiyah di Kabupaten Tulungagung). Surabaya. Fakultas Kesehatan Masyarakat UNAIR.

Rahmadanty, Cecia dan Masmira Kurniawati, 2015. Analisis Niat Perilaku Anggota Komunitas Hijabers Surabaya Dalam Menggunakan Tabungan Syariah : Perspektif Theory Of Planned Behavior. Program Studi S1 Manajemen Unair, 133.

Rorlen. (2007). Peran kelompok acuan dan keluarga terhadap proses keputusan untuk membeli. Business \& management journal bunda mulia. Vol: 3, No. 2.

Schiffman, L. G., \& Kanuk, L. L. (2007). Consumer behavior, 9th. International. Inc.: PrenticeHall.

Simamora, B. (2004). Panduan riset perilaku konsumen. Gramedia Pustaka Utama.

Taylor, S., \& Todd, P. (1995). Understanding household garbage reduction behavior: a test of an integrated model. Journal of Public Policy \& Marketing, 192-204

Ulfa, R., Wulandari, D., \& Subagio, N. A. (2014). Pengaruh Hijabers Community Terhadap Gaya Hidup Dan Keputusan Pembelian Hijab Pada Mahasiswa Fakultas Ekonomi Universitas Jember. e-Journal Ekonomi Bisnis dan Akuntansi, 1 (1), 67-71. 
Waluyo, M. (2011). Panduan dan aplikasi Structural Equation Modelling.Jakarta: PT. Indeks.

Wenger, E., McDermott, R. A., \& Snyder, W. (2002). Cultivating communities of practice: A guide to managing knowledge. Harvard Business Press.

Wijono, C.O. (2012). Fenomena Musik Jazz di Kalangan Gen Y Surabaya: Perspektif Theory Of Planned Behavior. Surabaya. Fakultas Ekonomi dan Bisnis UNAIR

Yogatama, L. A. M. (2013). Analisis Pengaruh Attitude, Subjective Norm, dan Perceived Behavior Control Terhadap Intensi Penggunaan Helm Saat Mengendarai Motor Pada Remaja dan Dewasa Muda di Jakarta Selatan. Prosiding PESAT, 5. 